\title{
Author Correction: Genomic risk score offers predictive performance comparable to clinical risk factors for ischaemic stroke
}

\author{
Gad Abraham, Rainer Malik, Ekaterina Yonova-Doing, Agus Salim, Tingting Wang, John Danesh, \\ Adam S. Butterworth (D), Joanna M.M. Howson (1), Michael Inouye \& Martin Dichgans (B)
}

Correction to: Nature Communications https://doi.org/10.1038/s41467-019-13848-1, published online 20 December 2019.

In the original version of this article, the affiliations of author Joanna Howson were incorrectly given as "British Heart Foundation Cardiovascular Epidemiology Unit, Department of Public Health and Primary Care, University of Cambridge, Cambridge, UK and Health Data Research UK Cambridge, Wellcome Genome Campus and University of Cambridge, Cambridge, UK". The correct affiliations are "British Heart Foundation Cardiovascular Epidemiology Unit, Department of Public Health and Primary Care, University of Cambridge, Cambridge, UK and National Institute for Health Research Cambridge Biomedical Research Centre, University of Cambridge and Cambridge University Hospitals, Cambridge, UK”.

In addition, the original version of this Article omitted the following from the Competing Interests statement: Dr Howson became a full time employee of Novo Nordisk while the manuscript was under review at Nature Communications.

These have been corrected in both the PDF and HTML versions of this article.

Published online: 20 February 2020

\footnotetext{
(c) (i) Open Access This article is licensed under a Creative Commons Attribution 4.0 International License, which permits use, sharing, adaptation, distribution and reproduction in any medium or format, as long as you give appropriate credit to the original author(s) and the source, provide a link to the Creative Commons license, and indicate if changes were made. The images or other third party material in this article are included in the article's Creative Commons license, unless indicated otherwise in a credit line to the material. If material is not included in the article's Creative Commons license and your intended use is not permitted by statutory regulation or exceeds the permitted use, you will need to obtain permission directly from the copyright holder. To view a copy of this license, visit http://creativecommons.org/licenses/by/4.0/.
}

(c) The Author(s) 2020 